\title{
Correction to: Impact of multiple cardiovascular medications on mortality after an incidence of ischemic stroke or transient ischemic attack
}

Tian-Tian Ma ${ }^{1}$, lan C. K. Wong ${ }^{1,2}$, Cate Whittlesea ${ }^{1}$, Kenneth K. C. Man ${ }^{1,2}$, Wallis Lau ${ }^{1,2}$, Zixuan Wang ${ }^{1}$, Ruth Brauer ${ }^{1}$, Thomas M. MacDonald ${ }^{3}$, Isla S. Mackenzie ${ }^{3}$ and Li Wei ${ }^{i^{*}}$

Correction to: BMC Med 19, 24 (2021)

https://doi.org/10.1186/s12916-021-01900-1

The authors of the original article [1] wish to amend the text in the Study design sub-section of the Methods section.

The text in this section should instead state the following:

"A cohort study was conducted using electronic primary healthcare data from the IQVIA Medical Research Data (IMRD) that incorporates data supplied by THIN (The Health Improvement Network), a propriety database of Cegedim SA."

\section{Author details}

'Research Department of Practice and Policy, School of Pharmacy, University, College London, London, UK. ${ }^{2}$ Centre for Safe Medication Practice and Research, Department of Pharmacology and Pharmacy, Li Ka Shing Faculty of Medicine, The University of Hong Kong, Pok Fu Lam, Hong Kong. ${ }^{3}$ Medicines Monitoring Unit (MEMO Research) and Hypertension Research Centre,

University of Dundee, Dundee, UK.

Published online: 12 September 2021

\section{Reference}

1. Ma T-T, Wong ICK, Whittlesea C, Man KKC, Lau W, Wang Z, et al. Impact of multiple cardiovascular medications on mortality after an incidence of ischemic stroke or transient ischemic attack. BMC Med. 2021;19:24 https:// doi.org/10.1186/s12916-021-01900-1.

The original article can be found online at https://doi.org/10.1186/s12916021-01900-1.

*Correspondence: I.wei@ucl.ac.uk

'Research Department of Practice and Policy, School of Pharmacy, University, College London, London, UK

Full list of author information is available at the end of the article

C The Author(s). 2021 Open Access This article is licensed under a Creative Commons Attribution 4.0 International License, which permits use, sharing, adaptation, distribution and reproduction in any medium or format, as long as you give appropriate credit to the original author(s) and the source, provide a link to the Creative Commons licence, and indicate if changes were made. The images or other third party material in this article are included in the article's Creative Commons licence, unless indicated otherwise in a credit line to the material. If material is not included in the article's Creative Commons licence and your intended use is not permitted by statutory regulation or exceeds the permitted use, you will need to obtain permission directly from the copyright holder. To view a copy of this licence, visit http://creativecommons.org/licenses/by/4.0/. The Creative Commons Public Domain Dedication waiver (http://creativecommons.org/publicdomain/zero/1.0/) applies to the data made available in this article, unless otherwise stated in a credit line to the data. 